\title{
Exchange Rate Volatility, the E.U. and Sectoral Exports: New Empirical Evidence from the Chemical Sector (1973-2005)
}

\author{
Dimitrios Serenis (Corresponding author) \\ Technological Educational Institution of Western Macedonia Branch of Kastoria, Department of International \\ Trade,
} Taxidrimiki thirida (PO Box) 807, Xloi, Kastoria, 52100, Greece

E-mail: dseren02@yahoo.com

Paul Serenis

Technological Educational Institution of Western Macedonia Branch of Florina, Department of Agriculture, M. Alexandrou 90, Florina 53-100, Greece

Received: October 12, $2010 \quad$ Accepted: October 22, $2010 \quad$ DOI: 10.5430/rwe.v1n1p47

\begin{abstract}
This paper examines potential effect of exchange rate volatility for a set of eleven E.U. member countries (Austria Belgium, Denmark, France, Finland, Italy, Portugal, Greece, Netherlands, the U.K. and Sweden) for sectoral trade exports of two products belonging to the chemical sector during the period of 1973-2005. We examine the effects of exchange rate volatility by utilizing a measure of the standard deviation of the moving average of the logarithm of real exchange rate as a measure of exchange rate volatility. Overall our results have proved to be consistent with our past examinations which for the main part did estimate some sectoral effects from volatility to exports. Further more the results of our estimation suggest a mixed relationship of volatility to trade.
\end{abstract}

Keywords: Exports, Sectoral trade, E.U., Exchange Rate Volatility

\section{Introduction}

With the move from fixed to flexible exchange rates in Europe in 1973, there was an increasing concern about effects of exchange rate variability on trade. Economic theory (Clark, P., 1973) suggests that exchange rate variability creates uncertainty with regard to the prices exporters would have to pay and receive in the future. More specifically, since most trade contracts incorporate payment lags to allow time for delivery or to provide trade credit they produce uncertainty over the future price of foreign currency and the importers' own profits. As a result, producers may prefer the possibility of more certain profits to the possibility of uncertain ones. Therefore, uncertain revenue will encourage producers to switch away from foreign markets to domestic ones, which in turn will cause a reduction in the level of exports. This is an argument for negative effects although it is possible, in certain theoretical models to have positive effects. Early empirical work seemed to favor negative effects although there were many findings of an insignificant relationship between export quantity and volatility. (Hooper, P. and Kohlagen, S., 1978).

In the 1980's (1980-1989) some positive and negative statistically significant relationships were found (Thursby, J. and Thursby, M, 1987) along with null results (Bailey, M., Tavlas, G.. and Ulan, M., 1986). Cushman published a series of studies (Cushman, D., 1983, 1986, 1988), using more advanced time-series methods than earlier studies finding mixed results. Later researchers have identified a positive relationship (Asseery, A. and Peel, D., 1991) while others identify negative (Arize, A., 1995, 1996, 2000) or in some cases no relationship at all (Arize, A., 1999). In the last period starting from 2000 and onwards there is some variation in the empirical research (Abbott, A., Darnell, A. and Evans, 2001; Doganlar, M., 2002; Du, H. and Zhu, Z., 2001; Bredin, Fountas and Murphy, 2003; Ozturk, I., 2006; Benson, U. and Godwin, A., 2010; Awokuse, T. and Yuan, Y., 2006; Mehari, W., 2006; Pattichis, Cheong, Mehari and Wiliams, 2004). This variation is with regard to the different sample countries, time periods as well as different volatility measures and different types of exchange rates used. With regard to the empirical estimation of the equations the bulk of the research utilizes mainly either ECM(Kargbo, J., 2006; Shehu, R., 2008; Abbott, A., Darnell, A. and Evans, 2001; Bredin, Fountas and Murphy, 2003) or ARCH-GARCH (Baum, Caglayan and Ozkan, 2006; Choudhury and Taufiq, 2005; Engle R., 
2004; Siregar, Reza, Rajan and Ramkishen, 2004; Linan, O. and Huseyin, K., 2009) estimation techniques. The variation with regard to the sample countries consists of four categories. These countries are: developed countries, developing countries, a mixed sample, containing European as well as other countries and finally a sample containing only European countries. For the most part the literature seems to examine developing countries (Shehu, R., 2008; Kargbo, J., 2006; Linan, O. and Huseyin, K., 2009; Benson, U. and Godwin, A., 2010) although there is some empirical work containing a mixture of various countries (Chit, Moe, Marian and Willenbockel, 2008; Hondroyannis, Swamy, Tavlas and Ulan, 2008; Kai-li, W., 2007). Finally the smallest part of the literature examines only European countries. With regard to the different types of effects the bulk of the literature examine aggregate effects of volatility on exports leaving a very small number of empirical work estimating sectoral effects (Mackenzie, M., 1998; Pattichis, Cheong, Mehari and Williams., 2004; Doyle, D., 2001; Kargbo, J., 2006; Awokuse, T. and Yan, 2006). The range of the estimated relationships between exports and exchange rate volatility remains the same as in the previous periods.

From all of the above it is evident that there is a smaller amount of empirical studies examining a sample of European countries and further more there is an even smaller amount of empirical evidence relating to sectoral effects from volatility to exports. The purpose of this paper is to provide some additional evidence with regard to the potential effects of volatility to sectoral exports by utilizing a set of European countries for which there is a small amount of empirical work. Another important aspect of the study is to examine whether there is a difference between aggregate and sectoral export effects. This distinction is one that empirical researchers often fail to make since it is possible to have different aggregate and sectoral effects for the same sample countries. This paper looks at the sectoral impact of exchange rate volatility on real aggregate exports for the countries: Austria Belgium, Denmark, France, Finland, Italy, Portugal, Greece, Netherlands, the U.K. and Sweden for 1973-2005. We use the standard deviation of the moving average of the logarithm of real exchange rate as a measure of exchange rate volatility. Overall our results suggest that exchange rate volatility has some effects on sectoral exports for these European countries.

\section{Methodology and Data}

\subsection{The countries and data}

Our previous empirical work on the effects of exchange rate volatility to aggregate exports (Serenis, D., 2006; Serenis, D., Cameron, S. and Serenis, P., 2008; Serenis, D. and Serenis, P. 2008; Serenis, D. and Serenis, P., 2010) has not been able to identify a significant relationship between exports and exchange rate and volatility. However our empirical work on exchange rate volatility to sectoral trade seems to suggest that for some countries and some products it is possible to estimate a significant relationship (Serenis, D., 2006; Serenis, D. 2009). Having examined in the past the effects of exchange rate volatility on the manufacturing sector we would like in this paper to provide some additional empirical examination by extending our investigation to include the effects of exchange rate volatility on a set of eleven European countries for two products belonging to one sector. That sector is the chemical sector. The reason for the selection of these sample countries and these products is on the basis that empirical literature has provided limited examination on the effects of exchange rate volatility to exports. We examine the effects of exchange rate volatility for: Austria Belgium, Denmark, France, Finland, Italy, Portugal, Greece, Netherlands, the U.K. and Sweden and for the time period of 1973-2005. All the data will be derived from OECD (Organization for Economic Co-operation and Development) with the exception of GDP figures which will be derived form Eurostat and the real effective exchange rates which will be derived from the IFS (International Financial Statistics).

\subsection{The selected sectors and products}

The selection of the specific sector as well as the products that will be utilized for all these countries is not an easy choice. There are many sectors and many products that are exported and therefore a huge variety of combinations between products and countries which can be used. Further more some countries export one product while others don't. Having examined products belonging to most of the other sectors in our previous empirical work we would like to extend our investigation by including the chemical products sector. Therefore we have selected one product form each sector that all of the countries in our sample export. The selected sectors as well as the selected products are presented in table 1.

$<$ Table 1 about here $>$

\subsection{Methodology and results}

Our research will utilize a reduced form equation similar to that of Arize. More specifically:

$\log (X)=\lambda 0+\lambda 1 * \log (P X / P w)+\lambda 2 * \log (G D P)+\lambda 3+\lambda 4 *(V)+\omega$

Where: 
$-\mathrm{X}$ is export quantities,

$-\mathrm{PX} / \mathrm{Pw}$ the relative prices,

-GDP real domestic GDP,

$-\mathrm{V}$ volatility (defined as the standard deviation of the moving average of the logarithm of real effective exchange rate).

$-\omega$ an error term

Furthermore we will estimate potential effects of volatility to the level of exports through the utilization of the error correction methodology. If the index of domestic capacity raises the country's capacity to produce increases and so will exports. We would therefore, expect $\lambda 2$ to be positive, on the other hand if the relative prices rise the demand for exports will fall so we would expect $\lambda 1$ to be negative (Goldstein and Khan, 1976). With regard to the effects of exchange rate volatility the expected result could be either positive, negative, or will have no effect.

\section{Empirical results}

\subsection{Unit root and co-integration}

Consistent with the error correction methodology we continue by presenting the results of the augmented Dickey Fuller unit root test as well as the Engle Granger co-integration test results for each product. The augmented Dickey Fuller unit root tests are presented in table 2 .

\section{$<$ Table 2 about here $>$}

As we can see from table 2 the results of our tests indicate that most of the countries in our sample contain at least one unit root. More specifically, for organic chemicals the real exports contain a unit root of order one (I(1)) for all the countries in our sample with the exception of Finland, Ireland (for which there is a unit root of order two) and the UK (for which there is no unit root). The GDP series on the other hand displays some variation in terms of its integration order when compared with the export quantity series. For the most part the GDP series is integrated with an order of two (I(2)) with the exception of :Austria, Greece, Italy, U.K., Denmark (for which there is integration of order one) and for France for which there is no integration. As for relative prices they mainly display an integration order of one (I(1)) with the exception of: Finland (for which there is an integration of order two I(2)) and Austria, France, Portugal and Ireland which display no integration for the relative prices. Finally volatility displays no integration at all partly due to the fact that it is already differenced. Similar results can be produced for organic chemicals. More specifically the real exports series is integrated with an order of one for most of the sample countries with the exception of the UK (with an integration of order two (I (2)) and Austria which contains no integration at all. On the other hand GDP variable is mainly integrated with an order of one I(1) with the exception of: Finland, Netherlands and Sweden for which it is integrated with an order of two I(2) and Ireland which displays an integration order of three I(3). Similarly the relative prices series is mainly integrated with an order of one I(1) with the exception of: Finland, Portugal and Sweden for which there is no integration. Finally as expected the volatility measure displays no integration.

\subsection{Engle Granger Co-integration test}

In addition to the augmented Dickey Fuller unit root test we will also examine the results of the Engle Granger cointegration test. The results of the cointegration test for each product are presented in table 3 .

$<$ Table 3 about here $>$

As we can see form Table 3, there are a few countries and products for which Co- integration is present. These countries are: Ireland, U.K. for organic chemicals and Ireland for inorganic chemicals.

\subsection{Results}

Given the presence of co-integration for the previously mentioned countries we employ an error correction model to estimate these countries equations. The results are presented in Tables (4-5).

$$
<\text { Table 4-5 about here }>
$$

For the most part all the control variables contain the expected signs (GDP, P). With regard to the remaining variable (volatility) most of the cases examined here had a positive coefficient for volatility with the exception of one country (the U.K.). However, for these four countries in our sample the volatility coefficients did not turn out to be significant. Due to the absence of co-integration for the remaining countries of our sample a model in first differences will be estimated. The results of this estimation are presented in tables 6-7

$<$ Tables 6-7 about here> 
Just as in the error correction model so as in the first difference model for the most part all the control variables contain the expected signs (GDP, P). With regard to the volatility variable most of the countries examined here present a negative relationship with the exception of eight countries. These countries are: Austria, Finland, Netherlands, and Portugal for organic chemicals; Austria, Italy Netherlands and Sweden for inorganic chemicals. However, only three of the estimated coefficients proven to be significant for volatility. These coefficients are: Netherlands (with a positive coefficient significant at $10 \%$ ), for inorganic chemicals; Italy (with a negative coefficient and significant at $15 \%$ ) and Portugal (with a positive coefficient at $18 \%$ ) for inorganic chemicals. However more one out of these three coefficients two were positive leaving the remaining one with a negative relationship which would indicate a mixed relationship of exchange rate volatility to exports.

\section{Concussion and policy implications}

\subsection{Policy implications}

The main reasoning for which economic research is preformed is in order to examine potential effects with regard to the economic policy. As with every research so as in this case our results can be used in order to suggest policy implications. Since the results of our study have suggested mixed results the effect of a policy which reduces volatility has to preform with the over all benefit in mind. In other words a policy which reduces volatility at a specific sector of a country for which there is a negative effect from volatility to exports will produce a financial gain to the specific sector and product. On the other hand a policy which reduces volatility will present a financial loss for a sector for which there is a positive relationship from volatility. As a result of this the financial gains and potential losses will have to be calculated for various products of a sector of a country, for which volatility turns out to be significant, in order to determine whether such a policy will have an over all benefit. Only in the event that such a policy (a policy reducing volatility) has an overall benefit it would be possible to be implemented in a country. Another issue that has to be considered is the amount of the total financial gain (in the case for which such a gain exists). If the amount of the potential gain is farley low it might not be worth while to impose such a policy. The effects of a volatility reducing policy have been examined to some extent in our previous empirical work (Serenis, D., 2006). However as it evident the effects of such a policy will require the examination of a vide variety of sectors and products. Therefore this it is an aria were our future research will focus on.

\subsection{Conclusion}

It has been argued by some empirical researchers that exchange rate volatility has a negative effect on the level of exports. However, our previous examination has shown that exchange rate volatility over all does not affect the aggregate level of exports and that the aggregate effects can be quite different than the sectoral ones. In this study we have been able to estimate the effects of exchange rate volatility using a sample of eleven E.U. countries. The results of our estimation has proven that although for the most part exchange rate volatility does not have any major effects on the sectoral level of exports it is possible for some countries and some products to estimate significant sectoral effects which is consistent with our previous empirical work. In this study out of twenty two estimated equations only three have proven to have a statistically significant relationship leaving the remaining ones with a negative (for the most part) but with an insignificant relationship. Further more out of these three significant relationships only one was negative and two were positive relationship which would indicate a mixed relationship of volatility to trade. As a result of this mixed relationship it is possible to have no effects on the aggregate level. We therefore conclude that over all exchange rate volatility has been able to produce some significant overall effects to sectoral exports in Europe which are quite different from the aggregate effects.

\section{References}

Abbott, A., Darnell, A. and Evans, L. (2001). The Influence Of Exchange Rate Variability On UK Exports Applied Economics Letters 8: 47-49

Aliyu, R. (2008). Exchange Rate Volatility and Export Trade in Nigeria: An Empirical Investigation online: http://mpra.ub.uni-muenchen.de/13490/

Arize, Augustine, Osang, T., and Slottje, D. (2000). Exchange Rate Volatility And Foreign Trade: Evidence From Thirteen LDC's Journal Of Business and Economic Statistics 18(1): 10-17

Arize, A. (1995). Trade Flows And Real Exchange Rate Volatility: An Application Of Cointegration And Error-Correction Modeling North American Journal of Economics and Finance 6(1): 37-51 
Arize, A. C. (1996). Real Exchange Rate Volatility And Trade Flows: The Experience Of Eight European Economies International Review of Economics and Finance 5(2): 187-205

Arize, A. (1999). The Demand For LDC Exports: Estimates From Singapore The International Trade Journal XIII (4): 345-369

Asseery, A. and Peel, D. (1991). The Effects Of Exchange Rate Volatility On Exports Economics Letters 37: 173-177

Awokuse, T. and Yuan, Y. (2006). The Impact Of Exchange Rate Volatility On U.S. Poultry Exports Agribusiness 22(2): 233-245

Bahmani-Oskoose, Mohsen and Goswami, Gour (2004). Exchange Rate Sensitivity Of Japan's Bilateral Trade Flows Japan and the World Economy 16: 1-5

Bailey, M., Tavlas, G. and Ulan, M. (1986). Exchange Rate Variability And Trade Performance: Evidence For The Big Seven Industrial Countries Weltwirtschaftliches Archive 122(3): 465-477

Baum, C., and Ozkan (2004). Nonlinear Effects Of Exchange Rate Volatility On The Volume Of Bilateral Exports Journal Of Applied Econometrics 19: 1-23

Benson, U. and Godwin, A. (2010). A Comparative Analysis of The Effect of Exchange Rate Volatility on Exports in the CFA and Non-CFA Countries of Africa Journal of Social Sciences 24(1): 23-31

Bredin, Fountas and Murphy (2003). An Empirical Analysis of Short-Run Irish Export Functions: Does Exchange Rate Volatility Matter? International Review of Applied Economics 17(2): 193-208

Cheong, Mehari, Williams (2006). Dynamic Links Between Unexpected Exchange Rate Variation, Prices, And International Trade Open Economies Review 17: 221-233

Chit, Moe, Marian and Willenbockel (2008). Exchange Rate Volatility and Exports: New Empirical Evidence from the Emerging East Asian Economies online: http://mpra.ub.uni-muenchen.de/9014/

Choudhry and Taufiq (2005). Exchange Rate Volatility And The United States Exports: Evidence From Canada And Japan Japanese Economies 19: 51-57

Clark, Peter (1973). Uncertainty, Exchange Rate Risk, And The Level Of International Trade Western economic journal 11: $302-313$

Cushman, David (1983). The Effects Of Real Exchange Rate Risk On International Trade Journal Of International Economics 15: 45-63

Cushman, David (1986). Has Exchange Risk Depressed International Trade? The Impact Of Third Country Exchange Risk Journal of International Money and Finance 5: 361-379

Cushman, David (1988). U.S. Bilateral Trade Flows and Exchange Risk During the Floating Period Journal of International Economics 24: 317-330

Doganlar, Murat (2002). Estimating The Impact Of Exchange Rate Volatility On Exports: Evidence from Asian Countries Applied Economics Letters 9: 859-863

Doyle, Eleanor (2001). Exchange Rate Volatility And Irish-UK Trade, 1979-1992 Applied Economics 33: 249-265

Du, H. and Zhu, Zhen (2001). Exchange Rate Risk In Exports: Some Additional Empirical Evidence Journal of Economic Studies 28(2): 106-121

Engle, Robert (2004). Risk and Volatility Models And Financial Practice The American Economic Review 94(3): 405-420

Herwatz, Helmut and Weber, Henning (2005). Exchange Rate Uncertainty And Trade Growth A Comparison Of Linear And Non Linear (Forecasting) Models Applied Stochastic Models In Business And Industry 21: 1-26

Hondroyiannis, Swamy, Tavlas and Ulan (2005). Some Further Evidence on Exchange Rate Volatility and Exports Bank of Greece working paper no 28

Hooper, Peter and Kohlhagen, Steven (1978). The Effect Of Exchange Rate Uncertainty On The Prices And Volume Of International Trade Journal Of International Economics 8: 483-511

Kai-Li, W. and Barret, C. (2007). Estimating the Effects of Exchange Rate Volatility on Export Volumes Journal of Agricultural and Resource Economics forthcoming 
Kargbo, Joseph (2006). Exchange Rate Volatility And Agricultural Trade Under Policy Reforms In South Africa Development southern Africa 23(1): 147-170

Levy-Yeyati, Eduardo and Sturzenegger, Federico (2003). To Float Or To Fix: Evidence On The Impact Of Exchange Rate Regimes On Growth The American Economic Review 93(4): 1173-1193

Lihan, O. and Huseyin, K. (2009). Exchange Rate Volatility and Trade : An Empirical Investigation from Cross Country Comparison African Development Review 21(3): 499-513

Lopez-Cordova, Ernesto and Meissner, Christopher (2003). Exchange-Rate Regimes And International Trade: Evidence Form Classical Gold Standard Era American Economic Review 93(1): 344-353

Mckenzie, Michael (1998). The Impact Of Exchange Rate Volatility On Australian Trade Flows Journal Of International Financial Markets Institutions And Money 8: 21-38

Ozturk, I. (2006). Exchange Rate Volatility and Trade: A Literature Survey International Journal Of Applied Econometrics and Quantitative Studies 3 (1): 86-102

Pattichis, Cheong, Mehari and Williams (2004). Exchange Rate Uncertainty, UK Trade And The Euro Applied Financial Economics 14: 885-893

Pattichis, Cheong, Mehari and Williams (2004). Exchange Rate Uncertainty, UK Trade And The Euro Applied Financial Economics 14: 885-893

Serenis, D. (2006). The Impact Of Exchange Rate Volatility On Exports: A Cross Country Analysis (1973-2004) PhD thesis, University Of Bradford

Serenis, D. (2009). The Impact Of Exchange Rate Volatility On Sectoral Exports (1973 - 2004) Atlantic Economic Journal: 2010, vol. 38, issue 1, pages 117-118

Serenis, D. and Serenis, P. (2010). The Impact Of Exchange Rate Volatility On Exports: Additional Evidance For Four European Countries (1973-2004) Journal of European Economy Volume: 3(1): 355-341

Serenis, D. and Serenis, P. (2010). The Impact Of Exchange Rate Volatility On Sectoral Exports: Evidance From Twelve E.U. Member Countries (1973-2004) Journal of European Economy: forthcoming

Serenis, D., Cameron, S., and Serenis, P. (2008). The Impact Of Exchange Rate Volatility On Exports: A Cross Country Analysis (1973 - 2004) Atlantic Economic Journal 36(3): 375-376

Serenis, Dimitrios, and Serenis, Paul (2008). The Impact Of Exchange Rate Volatility On Exports: Evidence From Four European Countries International Conference on Applied Economics: Kastoria-Greece, May 15-17

Siregar, Reza and Rajan, Ramkishen (2004). Impact Of Exchange Rate Volatility On Indonesia's Trade Performance In The 1990s Japanese International Economics 18: 218-240

Thursby, Jerry, and Thursby, Marie (1987). Bilateral Trade Flows, The Linder Hypothesis And Exchange Risk Review Of Economics And Statistics 69: 488-495

Table 1. Selected sectors and products

\begin{tabular}{|l|l|}
\hline Sector & Product \\
\hline Chemicals & Organic \\
\hline Chemicals & Inorganic chemicals \\
\hline
\end{tabular}


Table 2. Augmented Dickey Fuller unit root test results

\begin{tabular}{|c|c|c|c|c|}
\hline \multicolumn{5}{|c|}{ Organic Chemicals } \\
\hline Country & \multicolumn{4}{|c|}{ Variables and relationship } \\
\hline & Vex & GDP & V2 & P \\
\hline Austria & $\mathrm{I}(1)$ & $\mathrm{I}(1)$ & $\mathrm{I}(0)$ & $\mathrm{I}(0)$ \\
\hline Finland & $\mathrm{I}(2)$ & $\mathrm{I}(2)$ & $\mathrm{I}(0)$ & $\mathrm{I}(2)$ \\
\hline France & $\mathrm{I}(1)$ & $\mathrm{I}(0)$ & $\mathrm{I}(0)$ & $\mathrm{I}(0)$ \\
\hline Greece & $\mathrm{I}(1)$ & $\mathrm{I}(1)$ & $\mathrm{I}(0)$ & $\mathrm{I}(1)$ \\
\hline Ireland & $\mathrm{I}(2)$ & $\mathrm{I}(2)$ & $\mathrm{I}(0)$ & $\mathrm{I}(0)$ \\
\hline Netherlands & $\mathrm{I}(1)$ & $\mathrm{I}(2)$ & $\mathrm{I}(0)$ & $\mathrm{I}(1)$ \\
\hline Italy & $\mathrm{I}(1)$ & $\mathrm{I}(1)$ & $\mathrm{I}(0)$ & $\mathrm{I}(1)$ \\
\hline Portugal & $\mathrm{I}(1)$ & $\mathrm{I}(2)$ & $\mathrm{I}(0)$ & $\mathrm{I}(0)$ \\
\hline Sweden & $\mathrm{I}(1)$ & $\mathrm{I}(2)$ & $\mathrm{I}(0)$ & $\mathrm{I}(1)$ \\
\hline UK & $\mathrm{I}(0)$ & $\mathrm{I}(1)$ & $\mathrm{I}(0)$ & $\mathrm{I}(1)$ \\
\hline Denmark & $\mathrm{I}(1)$ & $\mathrm{I}(1)$ & $\mathrm{I}(0)$ & $\mathrm{I}(1)$ \\
\hline
\end{tabular}

\begin{tabular}{|c|c|c|c|c|}
\hline \multicolumn{5}{|c|}{ Inorganic chemicals } \\
\hline Country & \multicolumn{4}{|c|}{ Variables and relationship } \\
\hline & Vex & GDP & V2 & P \\
\hline Austria & $\mathrm{I}(0)$ & $\mathrm{I}(1)$ & $\mathrm{I}(0)$ & $\mathrm{I}(1)$ \\
\hline Finland & $\mathrm{I}(1)$ & $\mathrm{I}(2)$ & $\mathrm{I}(1)$ & $\mathrm{I}(0)$ \\
\hline France & $\mathrm{I}(1)$ & $\mathrm{I}(0)$ & $\mathrm{I}(0)$ & $\mathrm{I}(1)$ \\
\hline Greece & $\mathrm{I}(1)$ & $\mathrm{I}(1)$ & $\mathrm{I}(0)$ & $\mathrm{I}(1)$ \\
\hline Ireland & $\mathrm{I}(1)$ & $\mathrm{I}(3)$ & $\mathrm{I}(0)$ & $\mathrm{I}(1)$ \\
\hline Netherlands & $\mathrm{I}(1)$ & $\mathrm{I}(2)$ & $\mathrm{I}(0)$ & $\mathrm{I}(1)$ \\
\hline Italy & $\mathrm{I}(1)$ & $\mathrm{I}(1)$ & $\mathrm{I}(0)$ & $\mathrm{I}(1)$ \\
\hline Portugal & $\mathrm{I}(1)$ & $\mathrm{I}(1)$ & $\mathrm{I}(0)$ & $\mathrm{I}(0)$ \\
\hline Sweden & $\mathrm{I}(1)$ & $\mathrm{I}(2)$ & $\mathrm{I}(0)$ & $\mathrm{I}(0)$ \\
\hline UK & $\mathrm{I}(2)$ & $\mathrm{I}(1)$ & $\mathrm{I}(0)$ & $\mathrm{I}(1)$ \\
\hline Denmark & $\mathrm{I}(1)$ & $\mathrm{I}(1)$ & $\mathrm{I}(0)$ & $\mathrm{I}(1)$ \\
\hline
\end{tabular}

*All tests are performed using the 5\% level of significance*Vex the export quantity, GDP represents the real gross domestic product, V2 volatility and $\mathrm{P}$ is the relative prices of the each country to the world price *All tests are performed to a maximum of three lags* The Akaike info criterion was used in all of the tests

Table 3. Engle Granger Co-integration test

\begin{tabular}{|c|c|c|c|}
\hline \multicolumn{2}{|c|}{ Organic Chemicals } & \multicolumn{2}{c|}{ Inorganic chemicals } \\
\hline Country & Variables and relationship & Country & Variables and relationship \\
\hline Austria & No co-integration & Austria & No co-integration \\
\hline Finland & No co-integration & Finland & No co-integration \\
\hline France & No co-integration & France & No co-integration \\
\hline Greece & No co-integration & Greece & No co-integration \\
\hline Ireland & Co-integration & Ireland & Co-integration \\
\hline Netherlands & No co-integration & Netherlands & No co-integration \\
\hline Italy & No co-integration & Italy & No co-integration \\
\hline Portugal & No co-integration & Portugal & No co-integration \\
\hline Sweden & No co-integration & Sweden & No co-integration \\
\hline UK & Co-integration & UK & No co-integration \\
\hline Denmark & No co-integration & Denmark & No co-integration \\
\hline
\end{tabular}

All tests are performed using the $10 \%$ level of significance*Vex the export quantity, GDP represents the real gross domestic product, V2 volatility and $\mathrm{P}$ is the relative prices of the each country to the world price 
Table 4. Estimated error correction model regressions for organic chemicals

\begin{tabular}{|c|c|c|c|c|c|c|}
\hline Country & \multicolumn{6}{|c|}{ Variables } \\
\hline & Constant & P & GDP & V2 & ECM & Statistics \\
\hline Ireland & -0.291477 & -0.216317 & 4.115615 & 3.642106 & -0.708185 & D.W=1.44003 \\
& $(-1.164869)$ & $(-1.186715)$ & $(1.544134)$ & $(0.160658)$ & $(-3.738119)$ & S.E=0.666900 \\
& & & & & & R2=0.430863 \\
\hline UK & 0.011911 & -0.132897 & 1.133270 & -3.376663 & -0.322196 & D.W=1.47720 \\
& $(0.225073)$ & $(-1.405744)$ & $(0.559845)$ & $(-1.130809)$ & $(-1.214108)$ & S.E $=0.137189$ \\
& & & & & & R2=0.314132 \\
\hline
\end{tabular}

Table 5. Estimated error correction model regressions for inorganic chemicals

\begin{tabular}{|c|c|c|c|c|c|c|}
\hline Country & \multicolumn{6}{|c|}{ Variables } \\
\hline & Constant & P & GDP & V2 & ECM & Statistics \\
\hline Ireland & 0.002134 & -0.196204 & 0.529627 & 4.423556 & -0.421400 & D.W $=0.262537$ \\
& $(0.016400)$ & $(-1.139828)$ & $(0.396699)$ & $(0.37297)$ & $(-2.595586)$ & S.E $=0.358798$ \\
& & & & & & R2 $=0.717243$ \\
\hline
\end{tabular}

*Vex the export quantity, GDP represents the real gross domestic product, V2 volatility and $\mathrm{P}$ is the relative prices of the each country to the world price

Table 6. Estimated First difference regressions for organic chemicals

\begin{tabular}{|c|c|c|c|c|c|}
\hline Country & \multicolumn{5}{|c|}{ Variables } \\
\hline & Constant & $P$ & GDP & $\mathrm{V} 2$ & Statistics \\
\hline Austria & $\begin{array}{c}0.015085 \\
(0.142784)\end{array}$ & $\begin{array}{c}-0.073653 \\
(-0.447137)\end{array}$ & $\begin{array}{c}-1.322945 \\
(-0.309661)\end{array}$ & $\begin{array}{l}12.85978 \\
(0.837808)\end{array}$ & $\begin{array}{c}\text { D.W }=2.026477 \\
\text { S.E }=0.185924 \\
\text { R2 }=0.093036\end{array}$ \\
\hline Finland & $\begin{array}{c}0.091599 \\
(0.699421)\end{array}$ & $\begin{array}{c}-0.142046 \\
(-0.606789)\end{array}$ & $\begin{array}{c}3.972537 \\
(1.234999)\end{array}$ & $\begin{array}{c}8.760981 \\
(0.699016)\end{array}$ & $\begin{array}{c}\text { D.W }=1.951497 \\
\text { S.E }=0.504646 \\
\text { R2 }=0.094987\end{array}$ \\
\hline France & $\begin{array}{c}0.845718 \\
(1.392119)\end{array}$ & $\begin{array}{c}1.085754 \\
(1.271697)\end{array}$ & $\begin{array}{c}-24.57299 \\
(-0.973340)\end{array}$ & $\begin{array}{c}-27.20149 \\
(-0.378757)\end{array}$ & $\begin{array}{l}\text { D. } W=2.044875 \\
\text { S. } E=1.544905 \\
\text { R2 }=0.152135\end{array}$ \\
\hline Greece & $\begin{array}{c}0.400991 \\
(1.293332)\end{array}$ & $\begin{array}{c}-1.352088 \\
(-2.181007)\end{array}$ & $\begin{array}{c}-16.43713 \\
(-2.045409)\end{array}$ & $\begin{array}{c}-22.48308 \\
(-0.732251)\end{array}$ & $\begin{array}{l}\text { D.W }=2.623017 \\
\text { S.E }=1.504873 \\
\text { R2 }=0.261195\end{array}$ \\
\hline Netherlands & $\begin{array}{c}0.042426 \\
(1.002326)\end{array}$ & $\begin{array}{c}0.015154 \\
(0.193141)\end{array}$ & $\begin{array}{c}-0.412737 \\
(-0.274612)\end{array}$ & $\begin{array}{l}0.912772 \\
(0.180084)\end{array}$ & $\begin{array}{l}\text { D.W }=1.981436 \\
\text { S.E }=0.116142 \\
\text { R2 }=0.008609\end{array}$ \\
\hline Italy & $\begin{array}{c}-0.031414 \\
(-0.476220)\end{array}$ & $\begin{array}{c}0.136885 \\
(1.330946)\end{array}$ & $\begin{array}{c}4.111116 \\
(1.347649)\end{array}$ & $\begin{array}{c}-5.353390 \\
(-1.425003)\end{array}$ & $\begin{array}{c}\text { D.W }=2.320958 \\
\text { S.E }=0.177490 \\
\text { R2 }=0.174700\end{array}$ \\
\hline Portugal & $\begin{array}{c}0.231782 \\
(1.158955)\end{array}$ & $\begin{array}{c}-0.531524 \\
(-1.503527)\end{array}$ & $\begin{array}{c}0.884239 \\
(0.248330)\end{array}$ & $\begin{array}{c}45.26601 \\
(1.236241)\end{array}$ & $\begin{array}{c}\text { D.W }=1.175192 \\
\text { S.E }=0.895601 \\
\text { R2 }=0.134000\end{array}$ \\
\hline Sweden & $\begin{array}{c}0.048753 \\
(0.730719)\end{array}$ & $\begin{array}{c}-0.010024 \\
(-0.057581)\end{array}$ & $\begin{array}{c}-1.185232 \\
(-0.474095)\end{array}$ & $\begin{array}{c}-0.580381 \\
(-0.145226)\end{array}$ & $\begin{array}{c}\text { D.W }=2.156157 \\
\text { S.E }=0.178171 \\
\text { R2 }=0.040941\end{array}$ \\
\hline Denmark & $\begin{array}{c}0.207876 \\
(0.470454)\end{array}$ & $\begin{array}{c}-2.278126 \\
(-1.597150)\end{array}$ & $\begin{array}{c}6.248227 \\
(0.356782)\end{array}$ & $\begin{array}{c}-20.88420 \\
(-0.297674)\end{array}$ & $\begin{array}{l}\text { D.W }=1.967507 \\
\text { S.E }=1.515587 \\
\text { R2 }=0.136821\end{array}$ \\
\hline
\end{tabular}


Table 7. Estimated First difference regressions for inorganic chemicals

\begin{tabular}{|c|c|c|c|c|c|}
\hline Country & \multicolumn{5}{|c|}{ Variables } \\
\hline & Constant & $\mathrm{P}$ & GDP & V2 & Statistics \\
\hline Austria & $\begin{array}{c}-0.082260 \\
(-0.537220)\end{array}$ & $\begin{array}{c}-0.927652 \\
(-2.527420)\end{array}$ & $\begin{array}{c}1.314230 \\
(0.207771)\end{array}$ & $\begin{array}{l}17.46381 \\
(0.704239)\end{array}$ & $\begin{array}{l}\text { D.W }=1.823906 \\
\text { S.E }=0.282961 \\
\text { R2 }=0.540575\end{array}$ \\
\hline Finland & $\begin{array}{c}0.051848 \\
(0.626130)\end{array}$ & $\begin{array}{c}-1.068094 \\
(-4.184137)\end{array}$ & $\begin{array}{c}-1.197882 \\
(-0.590228)\end{array}$ & $\begin{array}{c}-2.026278 \\
(-0.278146)\end{array}$ & $\begin{array}{l}\mathrm{D} . \mathrm{W}=2.387654 \\
\mathrm{~S} . \mathrm{E}=0.305446 \\
\mathrm{R} 2=0.523624\end{array}$ \\
\hline Italy & $\begin{array}{c}-0.002211 \\
(-0.025182)\end{array}$ & $\begin{array}{c}-0.142136 \\
(-0.895773)\end{array}$ & $\begin{array}{c}0.400964 \\
(0.097354)\end{array}$ & $\begin{array}{c}5.324258 \\
(1.131231)\end{array}$ & $\begin{array}{l}\text { D.W }=2.601799 \\
\text { S.E }=0.228276 \\
R 2=0.125400\end{array}$ \\
\hline Netherlands & $\begin{array}{c}0.009693 \\
(-0.904642)\end{array}$ & $\begin{array}{c}-0.131416 \\
(-1.167569)\end{array}$ & $\begin{array}{c}1.974272 \\
(1.109679)\end{array}$ & $\begin{array}{c}9.957104 \\
(1.578006)\end{array}$ & $\begin{array}{l}\mathrm{D} . \mathrm{W}=1.607964 \\
\mathrm{~S} . \mathrm{E}=0.141155 \\
\mathrm{R} 2=0.230210\end{array}$ \\
\hline Portugal & $\begin{array}{c}0.122294 \\
(0.999955)\end{array}$ & $\begin{array}{c}0.103713 \\
(0.357337)\end{array}$ & $\begin{array}{c}-1.555436 \\
(-0.693534)\end{array}$ & $\begin{array}{c}-23.04767 \\
(-1.097349)\end{array}$ & $\begin{array}{l}\mathrm{D} . \mathrm{W}=2.647628 \\
\mathrm{~S} . \mathrm{E}=0.480632 \\
\mathrm{R} 2=0.079895\end{array}$ \\
\hline Sweden & $\begin{array}{c}0.065353 \\
(0.784859)\end{array}$ & $\begin{array}{c}-0.257566 \\
(-1.381378)\end{array}$ & $\begin{array}{c}0.357116 \\
(0.124241)\end{array}$ & $\begin{array}{c}1.024798 \\
(0.197347)\end{array}$ & $\begin{array}{l}\text { D.W }=1.450859 \\
\text { S.E }=0.248697 \\
R 2=0.091394\end{array}$ \\
\hline UK & $\begin{array}{c}0.010332 \\
(0.140948)\end{array}$ & $\begin{array}{c}-0.916695 \\
(-2.612380)\end{array}$ & $\begin{array}{c}-0.617904 \\
(-0.241646)\end{array}$ & $\begin{array}{c}-2.246265 \\
(-0.456705)\end{array}$ & $\begin{array}{l}\mathrm{D} . \mathrm{W}=1.821549 \\
\mathrm{~S} . \mathrm{E}=0.231018 \\
\mathrm{R} 2=0.322730\end{array}$ \\
\hline Denmark & $\begin{array}{c}0.272361 \\
(0.757151)\end{array}$ & $\begin{array}{c}0.996223 \\
(1.132542)\end{array}$ & $\begin{array}{c}-1.603169 \\
(-1.603169)\end{array}$ & $\begin{array}{c}-68.55809 \\
(-1.135278)\end{array}$ & $\begin{array}{l}\mathrm{D} . \mathrm{W}=1.816090 \\
\mathrm{~S} . \mathrm{E}=1.270341 \\
\mathrm{R} 2=0.102239\end{array}$ \\
\hline France & $\begin{array}{c}0.562094 \\
(0.922796)\end{array}$ & $\begin{array}{c}0.257604 \\
(0.171879)\end{array}$ & $\begin{array}{c}-13.43465 \\
(-0.511662)\end{array}$ & $\begin{array}{c}-51.77394 \\
(-0.718562)\end{array}$ & $\begin{array}{l}\mathrm{D} . \mathrm{W}=2.053019 \\
\mathrm{~S} . \mathrm{E}=1.558490 \\
\mathrm{R} 2=0.064006\end{array}$ \\
\hline Greece & $\begin{array}{c}0.363804 \\
(1.105696)\end{array}$ & $\begin{array}{c}0.475575 \\
(0.832495)\end{array}$ & $\begin{array}{c}-9.714177 \\
(-1.067050)\end{array}$ & $\begin{array}{c}-17.46681 \\
(-0.553651)\end{array}$ & $\begin{array}{l}\mathrm{D} . \mathrm{W}=2.096402 \\
\mathrm{~S} . \mathrm{E}=1.581553 \\
\mathrm{R} 2=0.103232\end{array}$ \\
\hline
\end{tabular}

*Vex the export quantity, GDP represents the real gross domestic product, V2 volatility and $\mathrm{P}$ is the relative prices of the each country to the world price. 